\title{
The Diagnostic Evaluation of Patients with Hereditary Ataxia in Children: Thirteen Patients And Comprehensive Approach
}

\author{
(iDCengiz Havalı ${ }^{1}$, (DD Zeynep Beyza Kuşku², (iD) Yılmaz Akbaş ${ }^{3}$ \\ ${ }^{1}$ M.D. Spec.,Bursa Yuksek intisas Training and Research Hospital, Department of Pediatrics, Division of Neurology, Bursa, Turkey \\ ${ }^{2}$ M.D. Spec., Bursa Yuksek Ihtisas Training and Research Hospital, Department of Pediatrics, Bursa, Turkey \\ ${ }^{3}$ M.D. Spec., Hatay Mustafa Kemal University Faculty of Medicine, Department of Pediatrics, Division of Neurology, Hatay, \\ Turkey
}

$\ddot{0 z}$

Çocuklarda Kalıtsal Ataksili Hastalarda Tanısal Değerlendirme: Onüç Hasta ve Kapsamlı Yaklașım

Amaç: Bu çalıșmanın amacı, oldukça nadir görülen kalıtsal ataksilerin genotip-fenotip özelliklerini tanımlayarak tanı koyma sürecine yardımcı olmaktır.

Yöntem: Son beș yıl içinde kalıtsal ataksi tanısıyla izlenen hastaların klinik, laboratuvar, elektrofizyolojik ve görüntüleme bulguları çeșitli fenotipik görünümleri ve genetik sonuçları sunulmuștur.

Bulgular: Dört hasta Friedrich ataksi, dört hasta Ataksi-Telanjiektazi, iki kardeș hasta BRF 1 gen ilișkili Serebellofasiyodental sendrom, bir hasta spinoserebellar ataksi tip 42, bir hasta Marinesco-Scogren sendromu ve bir hasta ataksi okulomotor apraksi tanısı almıștır. Öykü ve muayene bulguları, elektromiyografi, beyin manyetik rezonans görüntüleme, alfa fetoprotein düzeyleri tanı sürecinde kullanılan ilk basamak değerlendirmelerdir. Hastaların \%85’inde kesin tanıya genetik testlerle ulașılmıștır.

Sonuç: Kalıtsal ataksili hastaların kesin teșhisinde sistematik ve bütüncül yaklaşım önerilmektedir. Ataksinin bașlangıç yașı, seyri, ailede benzer hastalık varsa kalıtsal geçiș paterni, muayene bulgularına göre seçilecek yardımcı laboratuvar ve görüntüleme yöntemleri; ön tanı oluşturmada ve kesin teșhis için seçilecek genetik testlerin belirlenmesinde oldukça önemlidir. Tüm ekzom analizinin geniş kapsamına rağmen nükleotid tekrar hastalıkları, geniş delesyon ve duplikasyonların tespitinde yetersiz kalabileceği unutulmamalıdır. Anahtar Kelimeler: Ataksi, Otozomal Resesif, Serebellum, Çocukluk Çă̆ı

\section{Abstract}

\section{The Diagnostic Evaluation of Patients with Hereditary Ataxia in Children: Thirteen Patients and Comprehensive Approach}

Objective: This study aims to determine genotype-phenotype characteristics that can help diagnose hereditary ataxia, a rare disease. Methods: The findings of clinical, laboratory, electrophysiological, and magnetic resonance imaging of thirteen patients with ataxia in the last five years were reported in this study. Phenotypic expressions in patients with the genetically proved mutation were also reviewed.

Results: We report four patients identified with Friedreich's ataxia (FA) and four patients diagnosed with ataxia-telangiectasia (AT), one patient with spinocerebellar ataxia (SCA) type 42, one patient with Marinesco-Sjögren syndrome (MSS), two patients diagnosed with recently defined BRF 1 gene-related Cerebellofaciodental syndrome and one patient with ataxia-oculomotor apraxia (AOA) type 1. Clinical findings, neuroimaging, alpha-fetoprotein levels and electrophysiological findings were first-step tests in diagnostic evaluation. The diagnosis was defined in $85 \%$ of all patients with genetic studies.

Conclusion: A systematic investigation is recommended for definitive diagnosis in patients with hereditary ataxia. Age at onset of symptoms, prognosis, hereditary pattern of ataxia and clinical findings leads to choosing the ancillary tests, imaging, and genetic studies. The exome sequencing is not an all-knowing test and may fail to find trinucleotide repeats, large deletion and duplications. Specific genetic studies, including single-gene sequencing, microarray methods, should be kept in mind.

Keywords: Ataxia, Autosomal Recessive, Cerebellum, Children

Nasıl Atıf Yapmalı / How to Cite: Havalı C, Kușku ZB, Akbaş Y. The Diagnostic Evaluation of Patients with Hereditary Ataxia in Children: Thirteen Patients and Comprehensive Approach. MKÜ Tıp Dergisi. 2021;12(43):77-82. https://doi.org/10.17944/mkutfd.919601

Sorumlu Yazar/Corresponding Author: M.D. Spec. Yılmaz Akbaș

Email: mberf@hotmail.com

Geliș/Received: 18 Nisan 2021

ORCID iD: 0000-0003-3919-4685 


\section{INTRODUCTION}

The cerebellum assembles much sensory information from many brains, and spinal cord fields coordinate movements and contributes to motor planning and muscle tone. Hereditary ataxia is a heterogeneous group of diseases that may occur because of the cerebellum, brain stem, and spinal cord involvement. Gait disturbance, imbalance, speech, swallowing and oculomotor control disorders are common symptoms. They may be divided into the autosomal-recessive cerebellar ataxias (ARCA), the autosomal-dominant ataxia and $\mathrm{X}$-linked ataxia. More than 50 recessive ataxias and approximately 40 spinocerebellar ataxia (SCA) have been genetically defined (1).

Another group of ataxia inherited autosomal recessively is usually treatable. Biotinidase deficiency, pyruvate dehydrogenase deficiency, mitochondrial complex defects, abetalipoproteinemia, vitamin deficiencies are among partially treatable causes of ataxia. Congenital structural cerebellar anomalies, various neurometabolic diseases, including lysosomal storage disorders, peroxisomal disorders, urea cycle defects, can be included in ataxia causes (1).

The ARCA usually appears in the earlier period of childhood than the autosomal dominant syndromes. Many cases present without a family history of ataxia. The genetic causes should be considered on the list of differential diagnoses. Early-onset ataxia tends to be a more aggressive disease progression. ARCA is a rare disorder affecting the nervous system and organs associated with degeneration of the cerebellum and spinal cord. This group consists of many diseases, including Friedreich ataxia, ataxia-telangiectasia and ataxia with oculomotor apraxias (2).

This study consists of patients with various childhood-onset ataxia from a single tertiary centre in Turkey. We report four patients diagnosed with Friedreich's ataxia (FA) and four patients diagnosed with ataxia-telangiectasia (AT), one patient with spinocerebellar ataxia (SCA) type 42, one patient with Marinesco-Sjögren syndrome (MSS), two patients diagnosed with recently defined BRF 1 gene-related Cerebellofaciodental syndrome and one patient with ataxia-oculomotor apraxia (AOA) type 1.

\section{MATERIALS AND METHODS}

Thirteen patients who were diagnosed with ataxia were investigated retrospectively in this study. In the last five years, children admitted to our hospital with the initial complaint of pure ataxia were included. The patients who had ataxias with lysosomal storage diseases, mitochondrial diseases, organic acidurias, urea cycle defects, peroxisomal diseases and structural cerebellar anomalies were excluded from this study.

Data concerning clinical symptoms, demographic data, family history, disease course and laboratory investigations, including genetic studies, drug treatments, neuroimaging and electrophysiological findings, were collected.

\section{Genetic studies}

The GAA repeat analysis of the frataxin gene (FRDA) with sequence analysis of the entire coding region was performed on patients with FA.

The clinical exome study was used to diagnosed other causes of ataxia in the remained patients.

\section{DNA extraction}

GGenomic DNA from patients and their parents was obtained from peripheral venous blood samples. QIAamp ${ }^{\circledR}$ DNA Mini Kit for Genomic DNA detection (QIAGEN, Ankara, Turkey) was used.

\section{Sequencing for CES}

The Clinical Exome Solution (Sophia GENETICS) was used to exome enrichment for each patient. It is a capture-based target enrichment kit and covers 4.493 genes with known inherited disease-causing mutations. Paired-end sequencing was performed on an Illumina NextSeq 500 system with a read length of $150 \times 2$.

\section{Sanger Sequencing}

The probe and healthy family variations were determined. SP and AADC regions of the genes' variations were detected in the genes, Primer 3 software (http: // IHG. gsf.de/ihg/exonprimer.html) and $\mathrm{H}$ Taq polymerase (Zeydanli, Ankara, Turkey). Standard PCR conditions were used. Purification of the products was performed using the Zymo Research Sequencing Clean-up Kit (The Epigenetic Company, Irvine, USA). Loop sequencing was performed in the 3130 Genetic Analyzer (Applied Biosystems, Foster City, USA) with the Bigdye Terminator v3.1 Loop Sequencing Kit (Applied Biosystems, Foster City, USA). Data were analyzed using the sequencing analysis v5.3.1 program (Applied Biosystems, Foster City, USA) and compared to the reference sequence.

\section{RESULTS}

\section{Clinical findings}

Details on the study population are summarized in Table 1. Thirteen patients were included (five female, eight male). Patients 5 and 6, patients 9 and 10 were siblings. Age at study was 3-20 years (median ten years). Initial symptoms were evident in all patients but with FA in the first 24 months of life (particularly first-year age). Patients with FA presented with ataxia age of 7-12 years. The main clinical finding in all patients was ataxia. Developmental delaying, oculomotor apraxia, tremor, dysarthria were other symptoms along with ataxia. The age at diagnosis ranged from three to 18 years, 


\begin{tabular}{|c|c|c|c|c|c|c|c|c|c|c|c|}
\hline Case \# & $\begin{array}{l}\text { Current } \\
\text { age } \\
\text { (year) / } \\
\text { Gender }\end{array}$ & Symptoms & $\begin{array}{l}\text { Age of onset } \\
\text { of symptoms } \\
\text { (year) }\end{array}$ & $\begin{array}{l}\text { Age of } \\
\text { diagnosis } \\
\text { (year) }\end{array}$ & $\begin{array}{c}\text { Developmental } \\
\text { delaying/ } \\
\text { regression }\end{array}$ & $\begin{array}{l}\text { Cognitive } \\
\text { delay }\end{array}$ & Lab & Brain MRI & EMG & Treatment & Genetic/diagnosis \\
\hline 1 & $10 / F$ & $\begin{array}{l}\text { Developmental } \\
\text { delaying, } \\
\text { ataxia }\end{array}$ & 2 & 7 & $+/-$ & + & $\begin{array}{l}\text { AFP: } \\
156\end{array}$ & $\begin{array}{l}\text { Cerebellar } \\
\text { atrophy }\end{array}$ & - & - & AT \\
\hline 2 & $12 / \mathrm{F}$ & Ataxia, OA & 1 & 7 & $+/-$ & + & $\begin{array}{l}\text { AFP: } \\
175\end{array}$ & $\begin{array}{l}\text { Cerebellar } \\
\text { atrophy }\end{array}$ & - & - & AT \\
\hline 3 & $8 / F$ & Ataxia & 1.5 & 4 & $+/-$ & + & $\begin{array}{l}\text { AFP: } \\
157\end{array}$ & - & - & - & ATM homozygous /AT \\
\hline 4 & $7 / M$ & $\begin{array}{l}\text { Developmental } \\
\text { delaying, } \\
\text { Ataxia, OA }\end{array}$ & 2 & 4 & $+/-$ & + & $\begin{array}{l}\text { AFP: } \\
126\end{array}$ & & & & ATM homozygous /AT \\
\hline 5 & $11 / M$ & Ataxia & 7 & 8 & $-1+$ & - & - & - & $\begin{array}{l}\text { Sensory } \\
\text { neuropathy }\end{array}$ & Idebenone & $\begin{array}{c}\text { FXN GAA trinucleotide } \\
\text { repeat }>66 / \text { FA }\end{array}$ \\
\hline 6 & $18 / F$ & Ataxia & 8 & 18 & $-1+$ & - & - & - & $\begin{array}{c}\text { Sensory } \\
\text { neuropathy }\end{array}$ & Idebenone & $\begin{array}{c}\text { FXN GAA trinucleotide } \\
\text { repeat }>66 / F A\end{array}$ \\
\hline 7 & $15 / M$ & $\begin{array}{l}\text { Ataxia, tremor, } \\
\text { dysartria }\end{array}$ & 8 & 15 & $-/+$ & - & - & $\mathrm{N}$ & $\begin{array}{c}\text { Sensory } \\
\text { neuropathy }\end{array}$ & Idebenone & $\begin{array}{c}\text { FXN GAA trinucleotide } \\
\text { repeat }>66 / F A\end{array}$ \\
\hline 8 & $18 / M$ & Ataxia & 12 & 17 & $-1+$ & - & - & - & $\begin{array}{c}\text { Sensory } \\
\text { neuropathy }\end{array}$ & & $\begin{array}{c}\text { FXN GAA trinucleotide } \\
\text { repeat }>66 / F A\end{array}$ \\
\hline 9 & $7 / M$ & $\begin{array}{l}\text { Developmental } \\
\text { delaying, } \\
\text { ataxia }\end{array}$ & 1 & 7 & $+/-$ & + & & $\begin{array}{l}\text { Pontocerebellar } \\
\text { hypoplasia }\end{array}$ & - & & $\begin{array}{l}\text { BRF1 gene compound } \\
\text { heterozygous/ } \\
\text { cerebellofaciodental } \\
\text { syndrome }\end{array}$ \\
\hline 10 & $3 / M$ & $\begin{array}{l}\text { Developmental } \\
\text { delaying, } \\
\text { ataxia }\end{array}$ & 1 & 2 & $+/-$ & + & & - & - & & $\begin{array}{l}\text { BRF1 gene compound } \\
\text { heterozygous/ } \\
\text { cerebellofaciodental } \\
\text { syndrome }\end{array}$ \\
\hline 11 & $6 / M$ & $\begin{array}{c}\text { Developmental } \\
\text { delaying, 0A, } \\
\text { ataxia }\end{array}$ & 1 & 5 & $+/-$ & + & & $\mathrm{N}$ & - & - & $\begin{array}{c}\text { CACNA1G } \\
\text { heterozygous/SCA } 42\end{array}$ \\
\hline 12 & $20 / F$ & $\begin{array}{l}\text { Ataxia, tremor, } \\
\text { seizures }\end{array}$ & 11 & 16 & $-1+$ & - & & $\mathrm{N}$ & $\mathrm{N}$ & VPA & $\begin{array}{l}\text { APTX homozygous/ } \\
\text { Ataxia,early-onset, } \\
\text { with oculomotor } \\
\text { apraxia and } \\
\text { Hypoalbuminemia } \\
\text { (MIM N0:208920) }\end{array}$ \\
\hline 13 & $8 / F$ & $\begin{array}{c}\text { Developmental } \\
\text { delaying, } \\
\text { ataxia }\end{array}$ & 1 & 6 & $+/-$ & + & - & $\begin{array}{l}\text { Cerebellar } \\
\text { atrophy }\end{array}$ & - & - & $\begin{array}{l}\text { SIL1 homozygous/ } \\
\text { Marinesco-Sjogren } \\
\text { Syndrome (MIM } \\
\text { N0:248800) }\end{array}$ \\
\hline
\end{tabular}

Abbreviations: AFP; alpha-fetoprotein, AT; Ataxia-telangiectasia, F; female, FA; Friedreich ataxia, EMG; electromyography, FXN; frataxin, M; male, MRI; magnetic resonance imaging, OA; oculomotor apraxia, SCA; spinocerebellar ataxia, VPA; valproic acid 
and the delaying of diagnosis in patients was one to 10 years. In this study, all patients were diagnosed with cerebral palsy or undiagnosed. The cognitive delay was in all patients, excluding patients with FA.

\section{Laboratory tests and Imaging findings}

Biochemical studies of patients were unremarkable. Alpha-fetoprotein (AFP) level of patients with AT was found elevated around 10-15 times. Cerebellar atrophy was detected in patients 1, 2 with AT and 13 with MSS and pontocerebellar hypoplasia was revealed in patient 9 with Cerebellofaciodental syndrome on brain magnetic resonance imaging (MRI) (Figure 1). Electromyography (EMG) studies demonstrated sensory neuropathy findings in all patients with FA. Mild interseptal hypertrophy of cardiac muscle was found in patient 7.

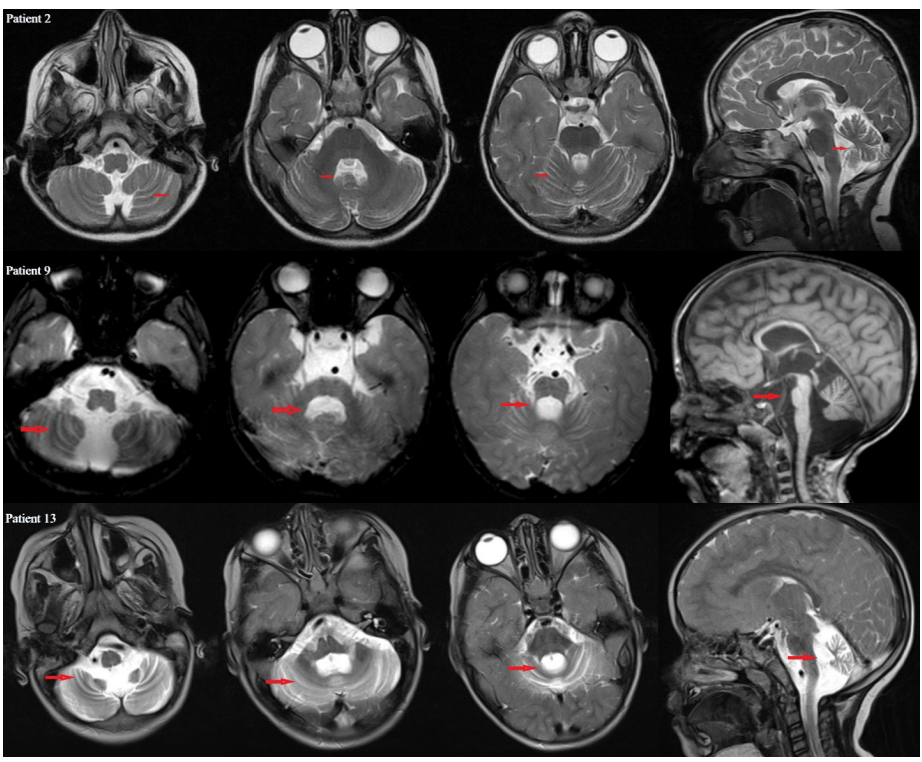

Figure 1: Brain MR imaging of patients 2, 9, 13 .

The images of patient 2 revealed mild cerebellar atrophy, particularly in the vermis. The same findings have been seen more as severe in patient 13. Hypoplasia of brainstem structures, including mesencephalon, pons and medulla oblongata, and cerebellum, were found on the MRI of patient 9 .

\section{Mutation analysis}

Genetic studies were performed on eleven patients and revealed ATM gene homozygous mutations in patients 3, 4 with AT, increased GAA repeat of the FRDA gene in patients 5 , $6,7,8$ with FA, BRF1 gene compound heterozygous mutation in patients 9, 10 with Cerebellofaciodental syndrome, CACNA1G gene heterozygous variation in patient 11 with SCA type 42, APTX gene homozygous mutation in patient 12 with AOA type 1, and SIL gene homozygous mutation in the patient 13 with MSS (Table 1). To our knowledge, these changes, which have not previously been reported in population studies, are classified as pathogenic according to ACMG criteria. In the silico analysis by Mutation Taster, Polyphen2, SIFT programs revealed their pathogenic effects.

\section{Treatment and prognosis of patients}

Physical therapy was initiated in all patients. Idebenone at $10 \mathrm{mg} / \mathrm{kg} /$ day was initiated in three patients with FA in the last four months. The evaluations of drugs' effects on the patients have been planned by the end of half-year. All patients can walk unsupported, but patient 6 had five points Gross Motor Function Classification System (GMFCS) score.

Valproic acid (VPA) treatment was initiated for patient 12 with seizure, and the patient had seizure-free for five years. Also, propranolol, primidone, was added to the patient's treatment for her tremor, but the improvement was not achieved. Clonazepam alleviated her tremor. The interrupting of VPA was attempted, but the patient lost the ability to walk. Therefore, VPA treatment was resumed, and the patient regained walkability with ataxia. Coenzyme q-10 was suggested to patients with APTX related AOA type 1, which was tried, but it did not affect.

All patients with AT were referred to related centres for evaluation of immunodeficiency and susceptibility to various neoplasms. One patient was monitored for humoral immunodeficiency and supported with monthly IVIG treatment.

\section{DISCUSSION}

Many classification systems were used to grouping causes of ataxia. Inherited pattern, clinical findings, age at the onset, curability were some main classification methods. ARCA represents the broad group inherited ataxias in childhood. The cerebellum and spinal cord degenerations characterise ARCA, early-onset occurring in childhood. Suggested ARCA classification based on the knowledge of the disease's pathogenesis as follows: congenital or developmental ataxias; metabolic ataxias (caused by enzymatic defects); ataxia with DNA repair defects; degenerative and progressive ataxic disorders such as Friedreich ataxia, and ataxias of unknown aetiology (2). All our patients but patient 11 have been included ARCA subgroup. Patient 11 has been linked to autosomal-dominant ataxia.

A systematic and comprehensive approach is essential to evaluate a child patient with ataxia. A complete clinical history and a flawless neurologic and physical examination are the first steps to elucidate disease diagnosis. The autosomal recessive genetic ataxias have been expanding along with implementing new methods to enhance genetic study (3). Today, exome sequencing is frequently used for the diagnosis of ataxia that begins in childhood. (4). However, it has no definite diagnosis and comprises all genetic defects, including increased trinucleotide repeat, some large deletions and duplications. Therefore, single-gene, various panels and chromosomal microarray testing could be used to diagnose 
some hereditary ataxia (4). We used the GAA repeat analysis of the frataxin gene in our patients with FA. Clinical history, age of onset, neurologic and physical examination and EMG findings comprise sensory neuropathy in these patients led us to FA prediagnosis. Observed characteristic conjunctival telangiectasias and increased AFP level have been sufficient to diagnose in all our patients with AT. The diagnosis has been confirmed genetically in our two patients. A clinical exome study covering 4449 gene and whole-exome sequencing was used to remain other patients with nonspecific clinical findings.

Brain MRI is a suitable method for evaluating the brain's structure. It suggests some specific diagnoses and eliminates others. It has been suggested that causes of childhood ataxia have been separated into two main categories, degenerative and malformation patterns. The degenerative pattern consists of volume loss (cerebellar atrophy) (5). Cerebellar atrophy is the main finding in FA, AOA type 1 and 2, A-T, and infantile-onset spinocerebellar ataxia (6). Cerebellar atrophy can be global or local; vermis is often affected. Atrophy can range from mild to severe, depending on many factors. (5). Signal intensity changes usually involve the white matter and appear T2/FLAIR sequences on brain MRI, especially in patients with cerebrotendinous xanthomatosis, infantile Refsum disease and various leukodystrophies. Cerebellar grey matter signal changes are present in the infantile neuroaxonal dystrophy, late infantile neuronal ceroid lipofuscinosis, mitochondrial disorders, or Marinesco-Sjogren syndrome (5). The malformation pattern is characterised by abnormal morphology of the brain stem and/or cerebellum, including dysmorphic or hypoplastic appearance. Congenital disorders of glycosylation, rhomboencephalosynapsis, Joubert syndrome, Dandy-Walker malformation, many malformations of cortical development, pontocerebellar hypoplasia may emerge with various malformation patterns (5).

Electrophysiological study of patients with ataxia can yield some valuable clues in the differential diagnosis. Peripheral nerve involvement with the dominance of sensory involvement in SCA and FA has been described (7). EMG is frequently normal in children with A-T. When peripheral neuropathy occurs with the progression of the disease, EMG shows signs of denervation. (8).

AFP measurement is a leading laboratory test in the investigation of patients with ataxia. Serum AFP and carcinoembryonic antigen (CEA) levels often elevate in affected individuals with A-T but not all patients. Telangiectasia usually occurs by the age of 5-8 years, particularly within the bulbar conjunctiva, but sometimes later or not at all in patients with A-T. Hence, the absence of telangiectasia does not exclude the diagnosis of A-T. Patients generally have decreased immunoglobulin (Ig) A and E, normal or increased IgM, G1 and G3 and decreased immunoglobulin G2 and G4 levels. These defects cause immunodeficiency $(1,8)$.

The six children with the cerebellar-facial-dental syndrome were characterised by dysmorphic features, short stature, microcephaly, mild-to-severe intellectual disability and scoliosis and laryngomalacia, which have been reported. Brain MRI revealed a similar pattern for pontocerebellar hypoplasia, with a thin corpus callosum, a flattened brainstem, and cerebellar vermis hypoplasia. Whole-exome sequencing revealed biallelic missense alterations of BRF1 in three families. The phenotype of these patients was described as a new autosomal recessive disorder. BRF1 mutations reduce protein activity and cause neurodevelopmental anomalies(9). Our sibling patients 9, 10 have exhibited developmental delay, ataxia, dysmorphic features and pontocerebellar hypoplasia.

Ataxia with oculomotor apraxia type1 is a rare autosomal recessive disease that arises from mutations in the APTX gene and presented with early-onset cerebellar ataxia, dysarthria, peripheral axonal neuropathy, muscle weakness, cerebellar atrophy, hypoalbuminemia and hypercholesterolemia, which become evident during late disease stages. Other features include mild to severe dystonia, intentional tremor and choreoathetosis (10). Our patient 12 with APTX gene mutation had ataxia, dysarthria, muscle weakness, tremor. The patient responded to VPA treatment, and her tremor decreased by VPA and clonazepam.

Marinesco-Sjögren syndrome (MSS) is characterised by cerebellar ataxia with cerebellar atrophy, dysarthria, nystagmus, early-onset cataracts, myopathy, muscle weakness and hypotonia. Diagnosis is achieved with typical clinical findings and biallelic pathogenic variants of the SIL1 gene on molecular genetic testing (1).

\section{CONCLUSION}

Evaluating and concluding a patient with ataxia may be challenging in the absence of obvious clues, including telangiectasia, a known similar diagnosis in the family. Specific laboratory tests can be helpful to investigate an accurate diagnosis. Nutritional causes include various deficiencies, such as vitamin B12, vitamin E, folate, and should be screened, especially in patients with restricted diets or malnutrition. Brain MRI should be an assessment tool that may demonstrate all kinds of pathologies, including congenital anomalies of the cerebellar and other brain structures. EMG is the other method that reveals any peripheral nerve involvement. Genetic studies are the most comprehensive procedure either in patients to have predicted diagnosis or lack of prediagnosis. Furthermore, we emphasize the exome sequencing is not an all-knowing test and may fail to find trinucleotide repeats, large deletion and duplications. Specific genetic studies, including single-gene sequencing, microarray methods, should be kept in mind. 


\section{ACKNOWLEDGEMENT}

Peer-Review

Externally Peer Reviewed

Conflict of Interest

The authors declare that they have no conflict of interests regarding content of this article..

Financial Support

The Authors report no financial support regarding content of this article.

Ethical Declaration

Ethical approval was obtained from University of Health Sciences, Bursa Yuksek Ihtisas Training and Research Hospital Ethics Comittee with date 2021/04-19 and number 2011KAEK-25, and Helsinki Declaration rules were followed to conduct this study.

\section{REFERENCES}

1. Paymaan J. N. SMM, Huda Y. Z. The Cerebellum and the Hereditary Ataxias. In: Swaiman KF, editor. Swaiman's Pediatric Neurology2018. p. 1564-94.

2. Palau F, Espinós C. Autosomal recessive cerebellar ataxias. Orphanet J Rare Dis. 2006;1:47. https://doi. org/10.1186/1750-1172-1-47

3. Fogel BL. Childhood cerebellar ataxia. J Child Neurol. 2012;27(9):1138-45. https://doi. org/10.1177/0883073812448231

4. Ignatius E, Isohanni P, Pohjanpelto M, Lahermo $\mathrm{P}$, Ojanen S, Brilhante V, et al. Genetic background of ataxia in children younger than 5 years in Finland. Neurology Genetics. 2020;6:e444. https://doi.org/10.1212/ NXG.0000000000000444

5. Vedolin L, Gonzalez G, Souza CF, Lourenço C, Barkovich AJ. Inherited Cerebellar Ataxia in Childhood: A PatternRecognition Approach Using Brain MRI. American Journal of Neuroradiology. 2013;34(5):925-34. https:// doi.org/10.3174/ajnr.A3055
6. Anheim M, Fleury M, Monga B, Laugel V, Chaigne D, Rodier G, et al. Epidemiological, clinical, paraclinical and molecular study of a cohort of 102 patients affected with autosomal recessive progressive cerebellar ataxia from Alsace, Eastern France: implications for clinical management. Neurogenetics. 2010;11(1):1-12. https:// doi.org/10.1007/s10048-009-0196-y

7. Myftiu B, Baslo M, Orhan E. Electrophysiological study of patients with spinocerebellar and Friedreich's ataxia. Neurological Sciencesand Neurophysiology.2018;35:13844. https://doi.org/10.5152/NSN.2018.11239

8. Schon K, van Os NJH, Oscroft N, Baxendale H, Scoffings D, Ray J, et al. Genotype, extrapyramidal features, and severity of variant ataxia-telangiectasia. Ann Neurol. 2019;85(2):170-80. https://doi.org/10.1002/ana.25394

9. Borck G, Hög F, Dentici ML, Tan PL, Sowada N, Medeira A, et al. BRF1 mutations alter RNA polymerase IIIdependent transcription and cause neurodevelopmental anomalies. Genome Res. 2015;25(2):155-66. https://doi. org/10.1101/gr.176925.114

10. Castellotti B, Mariotti C, Rimoldi M, Fancellu R, Plumari $\mathrm{M}$, Caimi S, et al. Ataxia with oculomotor apraxia type1 (AOA1): novel and recurrent aprataxin mutations, coenzyme Q10 analyses, and clinical findings in Italian patients. neurogenetics. 2011;12(3):193-201 https://doi. org/10.1007/s10048-011-0281-x 